\title{
Implementation of Diversion of Authority from District Forestry Office to Provincial Forestry Office under Act Number 23 of 2014 in Forestry Office of North Sumatra Province
}

\author{
Tunggul Sihombing \\ Department of Public Administration \\ University of Sumatera Utara \\ Medan, Indonesia \\ tunggul.toeng@gmail.com
}

\author{
Ridwan Rangkuti, Christopher Ondian Hutabarat, and \\ Asima Yanti Siahaan \\ Department of Public Administration \\ University of Sumatera Utara \\ Medan, Indonesia
}

\begin{abstract}
This research is based on the inability of local government in managing the governance in the forestry sector which resulted in the issuance of regulations to attract the implementation of forestry affairs by the district government to the province. Research conducted in North Sumatra Provincial Forestry Office aims to know the process of policy implementation which was determined by communication factor, resources, disposition of implementers, and bureaucratic structure according to the implementation model used. The research method is descriptive with qualitative approach adapting implementation model of George Edward III.
\end{abstract}

This Study find out that the implementation of diversion District Forestry Service to the province has been implemented well in which every single step is passed in accordance with the appropriate procedures. But it needs more supervision in upholding the discipline and improving the synergistic communication between the regency and the province. The improvement of office communication technology facilities and coordination through synergistic communication to the regency provides a supervision to every organization in the district that is part of the Forest Service of North Sumatra Province.

Keywords-Implementation, Diversion of Authority, Local Government.

\section{INTRODUCTION}

The progress of a nation is seen from the quality of policies that are decided and implemented in a nation. A solid or advanced nation is judged on the basis of the policies issued by its government in exercising the wheels of governance with programs that have been determined together. The role of science and technology in the administration of government is very rapid in creating an ideal policy in the 21 st century. But it seems that there are many things to consider in creating a precise and meticulous policy to support ideal governance.

Decentralization is transfered power by the central government to the regions to perform an important role that can be used as a tool of regional to develop their regency. Initially the central government believed that local governments were able to implement some of the implementation affairs given to the regions in the Act Number 32 of 2004, but there are some affairs of local government that shifted into the implementation of the central government. The disability is meant here especially for the management and utilization of the functions of the Forest Service established by the region.By saying central government must make andestablish a unity of services in maintaining the services and utilization of forests.

Forestry issues that illustrate forest destruction in North Sumatra are cited by the authors either the newspaper or article. Hundreds of Hectares of TahuraSibolangit Protected Forest Destroy (Kompas 2015), the destruction of Tahura forest is estimated to reach over 600 hectares. Others, LabuhanBatu Largest Contributors to Mangrove Forest Damage in North Sumatra (Rantauparapatnews August 7ᄀרth, 2015), informing about Labuhanbatu Regency contributing to the destruction of mangrove forest in North Sumatra with damage area reaching 121,702 hectares. The next article entitle Illegal Logging Destroy Adiankoting and Parlilitan Forest (Mongabaynews September 6th, 2015), occurred in HumbangHasundutan and North Tapanuli, North Sumatra. This actitvity made about 1,192 hectares of 74,852 hectares of protected forests are damaged.

Proven after the issuance of Act Number 23 of 2014 issued by the central government on the implementation of local government affairs, there are three areas of transition authority from the region to the center government namely education, health and forestry. Added again through the recapitulation of forest destruction and forest fire based on monitoring system owned by the Ministry of Environment and Forestry as follows:

Table Recapitulation of Fire and Forest Destruction in North Sumatra

\begin{tabular}{|c|c|c|c|c|c|c|}
\hline year & 2011 & 2012 & 2013 & 2014 & 2015 & 2016 \\
\hline $\begin{array}{l}\text { spacio } \\
\text { us (ha) }\end{array}$ & 5,00 & $\begin{array}{c}1.181 \\
, 00\end{array}$ & $\begin{array}{c}295,4 \\
0\end{array}$ & $\begin{array}{c}3.219 \\
90\end{array}$ & $\begin{array}{c}177,0 \\
0\end{array}$ & $\begin{array}{c}7.973 \\
01\end{array}$ \\
\hline
\end{tabular}


Source: Directorate of PKHL (Land and Forest Damage Control), Ministry of Environment

Explained in Act Number 23 of 2014, there are 3 government affairs.First,Absolute Government is a government affair entirely the authority of the central government. Second, affairs of the Concurrent Government are government affairs divided between the Central Government and the Provincial Region and the regency/municipalities, comprising the affairs of the Mandatory and Selective Concerning Governments. Third, General Government Affairs is a government affair that becomes the authority of the President as head of government. The affair of forestry isConcurrent Affair which has been taken over to the center by the province.

North Sumatra provincial government need to prepare the relevant agencies both from the completeness of personnel administration and the ability of the supporting apparatus. Organizations of agencies drawn to their respective centers are reviewed based on Government Regulation Number 18 of 2016. Things that need to be observed with changes in the implementation of local government affairs to the central government can be seen from the change of organizational structure of personnel, standard duties and responsibilities apparatus and adaptation of organization to organizational changes that occur. The preparedness of the North Sumatra Forestry Service would require special attention in finding attitudes in establishing regulations through the Regional Regulations and Governor Regulations to complement the technical implementation of policies due to policy changes.

Since the Forestry Service of North Sumatra Province has begun to implement this policy, the Technical Implementing Unit (UPT) in the regency also still encounters the provision of services and management in particular the problems in the field of personnel and of course the UPT is like a premature unit whichis not active well. Previously, the time span of UPT establishment made the Forestry office in abandoned areas considering the space and distance of each regency with the province is quite time consuming and of course the community directly to the provincial forestry department to take a lot of time. Besides, the mobilization of the civil apparatus in order to complete the administration of the office which is increasingly far seems to be causing a lot of significant problems to its performance in the respective UPT areas. Information of policy implementation which described above needs to be well reviewed, especially the process implementation of diversion of authority between district forestry and provinces office. It is necessary to know how the implementation process along with the related factors agree with the Act Number 23 of 2014.

\section{THEORETICAL REVIEW}

\section{A. Public Policy}

According to Dye, Public Policy is whatever the government choose to do or not (Nugroho 2006). Otherunderstandings of Policy can also be understood from theopinion of Anderson (Nurcholis 2007) Policy is seen as an action that has the purpose of a perpetrator or a number of actors to solve a problem.

Woll (Tangkilisan 2003), Public Policy is a number of government activities to solve problems in the community, both directly and institutionally that affect people's lives. In that definition, Woll states that the effect of such acts or activities of the government are: (1) The existence of policy choices made by politicians, government officials or others by using political power that can ultimately affect people's lives; (2) There is a policy output by making government policies required to make rules, budgets, personnel and regulations in the form of programs that will affect people's lives; (3) The impact of policies affecting people's lives.From this definition it can be stated that Public Policy is the regulations made by a group of people and the community to be obeyed and implemented in accordance with the law and the value set by the government as the holder of the policy authority.

\section{B. Policy Implementation}

Policy implementation is the most severe part of its implementation in policy, since problems encountered in the field are sometimes not found in the concepts found in the field. A public policy program should be implemented in order to have the desired impact or objective. A policy will only become elite records if the program is not implemented. Implementation of policies is seen in the broadest sense, is the stage of the policy process immediately after the enactment of legislation.

\section{RESEARCH METHOD}

This study uses qualitative research method by conducting in-depth interviews over linking variables based on George Edward III's opinion which suggests that policy implementation is determined by four variables: communication, resources, disposition and bureaucratic structure. Not only are the reserchers over linking the variables but also explore proses implementation of diversion of the district forest service to the province.

\section{RESULT AND DISCUSSION}

The implementation of government policy in diversion of the district forestry service to the provincial forestry service is an interrelated process between each momentum of its implementation. The descriptions of the interviews conducted are outlined based on the implementation model of Edward George III each component of the implementation has the following correspondence which is described below:

A. Communication, According to Edward III the first requirement for effective policy implementation is that those who implement the decisions must know what they should do. Policy decisions and orders must be forwarded to the right personnel before the decisions and orders can be followed. Communication process comprises three important things namely transmission, consistency, and clarity.

1. Transmission, before a policy can be implemented, the policy implementer must understand that a decision is made in 
order to execute the issues. Act Number 23 of 2014 on Regional Government was ratified in October 2014 by the President of the Republic of IndonesiaSusiloBambangYudhoyono and enacted in the same month by GamawanFauzi the Minister of Home Affairs.

This policy hasimplemented since November4th 2016 approximately 2 years after the enactment ofAct Number 23 of 2014 on Regional Government. Implementation of diversion of the district forestry service to the provincial forestry service is forwarded to the submission of documents, facilities and infrastructure and personnel owned by the local government of North Sumatra. Delivery of documents, facilities and infrastructure, and personnel represented by District Secretary to Regional Secretary North Sumatra province (Mr. HasbanRitonga)

On Friday November 4th, 2016, held at the Office of the Governor of North Sumatra Jln. P. Diponegoro Number 30 Medan, submission of documents, facilities and infrastructure began to be done. It was expected that the process of submitting data requested by the provincial government could be gathered entirely in 2016. The delivery of facilities and infrastructures is a form of submission in files and data whether in the form of human resources (personnel), equipment and machinery, buildings, irrigation, roads, networks, and other assets. Parties to the regional heads represented by the respective secretaries shall hand over personnel, facilities and infrastructure, and documents to the Provincial Secretariat regarding the affairs of the administration of the forestry sector from the district government to the provincial government provided that all submitted files become provincial optimally utilized for the sake of execution of government duties and service to society in the framework of national development.

Based on the results of the study through interviews with informants can be understood that the handover of personnel, facilities and infrastructure and documents accompanied by other parties as a witness, witnesses who enforced here are witnesses from the first party they all Chief District Forest Service and the second party Head of Provincial Forestry Office by Mr. Halen Purba. It is also explained that the submission is included in the minutes of events. Each copying file was given to first and second parties, the Minister of Home Affairs, the Minister of Finance, the Minister for Empowerment of State Civil Apparatus and Bureaucracy Reform, the Head of the State Personnel Board, Agency for Financial and Development Supervision and to the National Archives of the Republic of Indonesia.

After that the original file delivered from the Office of the Governor of North Sumatra to the State Personnel Agency which is located at Jln. TB Simatupang Number 124, Medan City North Sumatra. This data are then processed and followed up in a few weeks, then the news of the event received by the office of forestry service of North Sumatra province which is located at Jl. Sisingamaraja Number 14. According to informants at the stage of entry into the office of Forestry is the stage of financing of personnel, funding, facilities and infrastructure starting on January 1st, 2017. Previously though the handover of personnel, facilities and infrastructure, and documents carried out in November 2016 but with regard to personnel spending consisting of Basic Salary, Family Benefit, Job Allowances and other Benefits shall be the responsibility of the respective district governments up to December 31st, 2016.

Employees in the district area dated January1stare not many who came reporting themselves with a file transfer SK (Letter of official statement)which was signed by the head of the region to be forwarded to the Province. However after Regulation Minister of Home Affairs Number 120/125/SJ regulates the submission of personnel, facilities, and documents issued in January 2017 that bold to every employee who does not register and take not of the file to the Province theirofficial data would be removed from the BKN and not registered to civil servants. Revolving after this Minister of Home Affairs is issued then Civil Servants who work in the region immediately pass file arrangements to the province. Civil Servants who come to the North Sumatra provincial forestry office fill the file in the Sub Division of General Administration and Data processing employees by bringing the letter of SK along with other copy of the file to be verified by the Forest Service of the Province of North Sumatra. After that every employee who has done the administrative process opened an account that is used as revenue and salary delivery by the Province to the employees.From all the important eventsabove indicate that the implementation of Act Number 23 of 2014 at the offices of North Sumatra Provincial Forestry Service shall be carried out in accordance with the policies issued by the government and implemented on the orders of the policymakers.

2. Clarity, a policy requires clear and understandable communication by the implementer. In order for the transmission process to be effective then the process of transmitting or transforming information must be done intensively so that the implementer understand what the targets will get according to Act Number 23 of 2014 in the Transfer of the District Forest Service to the Province. There are two steps in the implementation of public policy that directly implement it in the program or first pass the policy derivative of public policy. Act Number 23 of 2014 requires an explanatory policy or implementing regulations.

Not only is PP Number 18 of 2016 used by Province forestry service but also Local Regulation Number 6 of 2016 about the Establishment of Regional Devices of North Sumatra Province.It set and signed by task executor of North Sumatra Governor TengkuErryNuradi where the position of this law is the same as the Act Number 23 of 2014 which requires implementing instructions. Implementation instructions is issued through North Sumatra Governor Regulation Number 38 of 2016 on the Description of Duties, Functions and Working Procedures of the North Sumatra Provincial Forestry Office. Clarity about the contents and ordinances guidelines loaded in the draft policy above can be understood by the implementer easily to be implemented.

The head of the agency led the internal meeting held at the Provincial Forestry office. This meeting was held several times before the receipt of filing up to the process of filing employees in the Forest Service of North Sumatra Province. 
This situation is described as a form of democratic policy implementation in the office, a space for every employee involved in understanding tasks and functions to help this policy a success. From January to March 2017 employee's data are completed and every staff in the district has joined the Technical Implementation Unit (UPT) that has been established accordance with the implementing regulations previously issued. UPT consists of 16 UPT Unity of Forest Management and 1 UPT Bukit Barisan Forest Park which can be mentioned 17 UPT and they divided into 16 Territory of Forest Management Unit. Each UPT is assisted by a Forest Protection Management Unit (KPHL) and Unit of Production Forest Management Unit (KPHP).

B. Resources, Implementing the policy carefully, clearly and consistently is not enough to produce effective implementation without the support of adequate resources. The resources needed in the implementation of the transfer of the local Forest Service to the provincial Forest Service are human resources as policy implementers, information on how a policy, authority possessed in the implementation of programs and facilities in implementing the policy can be achieved. Resources are not only limited to resources but also reliable source of implementation that can help implementation more effectively to achieve better goals.

1. Staff and Number of Personnel, Human resource executing in implementing the transfer of District Forest Service to Province is staff involved in managing administrative data at Forest Service Office of North Sumatera Province which is execution of policy and service provider to district officer who will provide the complete file. The availability of 18 active staff members in the North Sumatra provincial forestry office in the public section of the civil service is clearly seen as something positive in the implementation of the policy as it is considered to be sufficient to deal with all stages of filing in the implementation of district to provincial personnel transfers. There are things to keep in mind that a large number of staff doesn't automatically push for implementation to work properly. Without a strong sense of responsibility and commitment from the implementer to implement a policy as well as possible.

The staffsdo the tasks in accordance with their parts. These tasks are divided into several parts namely Processing Administration, Data Processing, Administration Letter, and General Administration. The staffs who undertake this assignment have rich experience and senior age to carry out administrating or processing data. Administrative staff checked local officials who came to complete the file and then file submitted to the general administration and mail for marking and mailing the incoming files and then processed by the employee data manager.

Office facilities are support to launch the implementation of the duties of employees in the office of North Sumatra Provincial Forestry Service which marked by the number of computers consisting of 5 units, a table consisting of more than 8 units, a seat consisting of more than 12 units that can be said to be adequate in conducting the implementation of the policy in the sub-section of the civil service. In addition to adequate facilities, the Forest Service office is also in a strategic position so that it is easy to be accessed by local officials who come far from out of town which directly cross the big road where the office is located.

Regarding the files and requirements required by local officials to be brought to the province has been informed in advance through the local Forestry Service where the employees work so that they no longer have to trouble in understanding what files they need to bring to the Provincial Forest Service office. The time required by the local officials to take care of the file at the Provincial Forestry Office is not too heavy and takes a long time just a few hours all the affairs of each employee can be completed and returned to their place where they come from.

2. Information is the most important resource that becomes the pulse in the direction of the next direction of action after the human resources in the implementation of the policy. Information illustrates how to implement a policy and with the availability of required data on government regulations. The policy implementers are provided with guidance which may include regulations on technical guidance and implementation guidance.

Technical guidance on this implementation is the Environmental and Forestry Agency P.74 of 2016 provides for the nomenclature of the organizational structure of provincial and regional forest services. Beside that used Governor Regulation Number 38 of 2016 on technical implementation of local government organizations in Act Number 23 of 2014.

The avability of guidelines can be concluded that the implementation of government policy for diversion of personnel in North Sumatra Provincial Forestry Office has been well implemented. The information obtained from interviews with informants and with observations directly conducted at the charged place together with a copyof the guidelines they have for the authors.

3. Authority, the implementation of authority vary from program to program and has many different forms. The authority that the authors want to see here is the authority in carrying out a task that should be done immediately because it concerns the success of a policy implemented.

The proper exercise of authority can be observed in the office and by interviewing informants. The transfer of the District Forestry Service to the Provincial Forestry Service runs gradually from the filing stage, document verification, and placement of local officials. The local employee does not seem to be burdened in completing the file and can quickly get to the UPT where he works. This authority is granted under binding rules, for example North Sumatra Provincial Office of Forestry Office does morning assemble at 8:00 am. This assemble is carried out by the Head of Department, Head of Section that each takes turns and has been determined. In the sphere of work done in the office each head of department is also responsible for overseeing and commanding every affair in the sub section he heads. 
C. Disposition, the tendencies of the implementer in implementing the policy can be an inhibiting factor. The tendencies here are the nature and characteristics of the implementer, such as honesty, sincerity, commitment, responsibility and democratic attitudes. The characteristics of the implementer here will be the support or obstacle in implementing the transfer of the District Forestry Service to the Provincial Forestry Service.

Forest Service Office celebrated the meeting headedby the head of the department. The gathering of personnel discussing how the implementation of a policy is taken seriously by the Provincial Forest Service staff, and understand the duties entrusted so it can easily do. Employee discipline must also be enforced by ensuring every member works on the assigned task. Surveillance must be the determining factor of every employee in the office. They allowed to fill the absence after lunch and then work hours will end at 15:30 pm.

Head of Service coordinates directly with UPT to integrate inter-organization relationship to synchronize task or man task that done. The Head of the Office is fully responsible to report to his superior the Governor in monitoring the progress of performance or achievement of the vision and mission determined beforehand. The head of the UPT shall be fully responsible to the head of the Service for all reports, his duties which within the prescribed time receive guidance from the head of service and attend certain meetings which are occasionally carried out.

D. Bureaucratic Structure, organizational structure in implementing policy has a significant influence on policy implementation. One of the most important aspects of organizational structure of any organization is the regulation that serves as an organizational technical guidance that each implementer guides to act.

The type of the North Sumatra Provincial Forestry Service is a Type "A" Forest Service. The Forestry Service Type A is the Forestry Service with a large workload.The North Sumatra Provincial Forestry Service has the same organizational structure before Act Number 23 of 2014 which distinguishes the head of Forestry Office of North Sumatra directly under the UPT and TAHURA in each designated area. The Organization of the North Sumatra Provincial Forestry Service consists of Head of Department, Secretary, Public SubDivision, Program Sub-Division, Financial Sub-Division, Forest Stewardship Area, Forest Exploitation, Forest Rehabilitation Section, Forest Protection Section and its Section.

On the other hand district forestry office became UPT which consists of Head of UPT, Sub Division of Administration, Section of Forest Planning and Exploitation, Forest Protection Section and Empowerment, and Functional Group of Occupation. The organizational structure in the district / city is very different from the previous organization where some parts are eliminated and downsized. Because the structure of the district forestry departmental consisted of the Head of the District Regional Forestry Office, Planning, Field of Protection and Preservation, Field of Exploitation a, the
Empowerment and the Section for each parts of all sectorsnow have been abolished.

\section{CONCLUSION}

a) This study is a policy aimed at improving the sustainability, exploitation and processing of forest well in the region. All forms of policy issued in the implementation of the transfer of the District Forestry Service to the Provincial Forestry Service shall be conducted solely for the development and development of the environment, especially in the regions. All activities undertaken in the execution of the assignment are carried out in accordance with all applicable regulations and following each stage regulations issued by the government to achieve better organizational reform.

b) The procedure for implementing the transfer of the District Forestry Service to the Provincial Forestry Service has been conducted to help meet the requirements of administrative standards in accordance with the regulations for the sake of continuity of implementation. Implementation Procedures have been carried out systematically based on the implementation guidance which is the guidelines of the implementer guided by Government Regulation, Ministerial Regulation, and Governor Regulation.

c) Communicationisimportant factor underlying the implementation of policy implementation of the transfer of District Forest Service to the Province which has been demonstrated through the description of policy communication during the transition period, the clarity of the content of the policy, and the consistency of the implementers who have done well.

d) Resource, human resource factor becomes the largest indicator of implementation in implementing government policy on transfer of District Forest Service to Province. The resources are in the criteria capable, although noted the need for improvements in the quality of human resources as well as the improvement and addition of facilities that are more supportive for the implementation of this policy.

e) Disposition, traits and tendency of implementers in the implementation of this policy can be said well because the implementer put forward the attitude of honesty, commitment, responsibility and democratic attitude in every step.

f) Organizational structure, the procedures of organization have been implemented accordingly. The changes in organizational structures can be an opportunity to coordinate effectivelyand with positive impacts on regional organizations, although there are some changes that eliminate some important positions in the Civil State Apparatus.

\section{SUGGESTIONS}

a) North Sumatra Provincial Forestry Office should add facilities such a facility that can be added for office equipment that supports administration as improvement of computer medium either software or hardware device. Computer units are also required for communication tool that can coordinate all the regional organizations of the district and province to more synergize. Sustainable education and training are also 
very necessary for the employees of the functional group to improve the maximum quality of work.

b) North Sumatra Provincial Forestry Office is also expected to be more intensive to supervise employees in the office by paying attention to attendance, making a list of rules of duty inwall magazine, and giving warning to employees who considered neglect the task or responsibility for the better.

\section{References}

[1] Arikunto, Suarsini, 2002, Research Procedure: A Practice Approach, Publisher Rineka Cipta, Jakarta.

[2] Bungin, M.Burhan, 2007, Qualitative Research, Publisher Pustaka Grahatama, Bandung.

[3] Dunin, Sudarman, 2002, Becoming Qualitative Researcher, Loyal Pustaka, Bandung.

[4] Dunn, William, 2003, Introduction to Public Policy Analysis: Second Edition, Gajah Mada University Press, Yogyakarta.

[5] Fathoni, Abdrrahmat, 2006, Organization and Human Resource Management, Publisher Rhineka Cipta, Jakarta.

[6] George, A. Steiner, 1997, Management Policy and Strategy, Erlangga Publishers, Jakarta.
[7] Mukarom, Laksana, 2015, Public Service Management, PT Raja Grafindo, Bandung.

[8] Nugroho, Riant, 2011, Public Policy, PT. Elex Media Komputindo, Jakarta.

[9] Nuradi, Tengku Erry, 2016, Pergub. 38 Year 2016 about Job Description, Functions and Working Procedures of North Sumatra Provincial Forestry Office, Pemda, Medan.

[10] Nurcholis, Hanif, 2007, Theory and Practice of Governance and Regional Autonomy, PT. Grasindo, Jakarta.

[11] Sugiyono, 2009, Research Methods Administration, PT. Alfabeta, Bandung.

[12] Sofian Effendi, Tukiran, 2012, Survey Research Methods, LP3ES, Jakarta.

[13] Tangkilisan, Hesel Nogi, 2003, Public Policy Implementation (Concept, Strategy, and Case), Lukman Offset YPAPI, Yokyakarta.

[14] Wahab, Solichin Abdul, 2008, Introduction to Public Policy Analysis, UPT Publishing University of Muhammadiyah, Malang.

[15] Wahab, Solichin Abdul, 2004, Policy Analysis from Formulation to Implementation of State Policy, Bumi Aksara, Jakarta.

[16] Widodo, Jokowi, 2016, Government Regulation no. 18 of 2016 about the StructureLocal Government Organization, Ministry of Home Affairs, Jakarta.

[17] Yudhoyono, Susilo Bambang, 2014, Law Number 23 Year 2014 aboutLocal Government, Ministry of Internal Affairs, Jakarta. 